\title{
SYNTHESIS, CHARACTERIZATION, ANTIMICROBIAL AND ANTI-INFLAMMATORY STUDIES OF SOME NOVEL SCHIFF BASE METAL COMPLEXES DERIVED FROM THE DRUG, DICLOFENAC
}

\author{
Kondareddy Gopinath Shilpa ${ }^{\bowtie}$, Kengunte Halappa Shivaprasad \\ and Medehal Rudrannagari Archana \\ Department of Chemistry, Vijayanagara Sri Krishnadevaraya University, Ballari-583105, \\ Karnataka, India \\ ${ }^{\square}$ Corresponding Author:kg4945@gmail.com
}

\begin{abstract}
The synthesis of Schiff base transition metal complexes always appears to be fascinating because of the possibility of obtaining coordination compounds of unusual structure and stability. These compounds possess special attention in the field of pharmaceuticals because of their wide spectrum of biological applications. Schiff base complexes form versatile compounds which actively take part in metalloenzymes and also can act as biomimetic models because of their closeness to natural proteins and enzymes. Hence, the present paper mainly aims in the synthesis of Schiff base ligand by modifying the functional group of the drug, diclofenac and using that Schiff base ligand four novel metal complexes of $\mathrm{Cu}(\mathrm{II}), \mathrm{Co}(\mathrm{II}), \mathrm{Ni}(\mathrm{II})$, and $\mathrm{Zn}$ (II) were prepared. The nature of bonding and the stereochemistry of the metal complexes can be deduced from elemental analyses, molar conductance, magnetic susceptibility, IR, electronic, ${ }^{1} \mathrm{H}$ NMR and Mass. The analytical data reveals that the metal to ligand ratio is 1:2. Due to lower molar conductivity values, the metal complexes are considered nonelectrolytes. The spectral analysis data describes that all the metal complexes possess octahedral geometry. The drug diclofenac synthesized Schiff base ligand and novel metal complexes were subjected to antimicrobial as well as anti-inflammatory activities. The Schiff base ligand and metal complexes show promising biological activities.
\end{abstract}

Keywords: Coordination Compounds, Schiff Base, Metal Complexes, Diclofenac, Antimicrobial, Antiinflammatory.

RASĀYAN J. Chem., Vol. 14, No.4, 2021

\section{INTRODUCTION}

For decades, coordination chemistry seems to be a topic of inquisitiveness as it involves the synthesis of the diversity of ligands containing different functional groups and coordinates with metal ions of variable oxidation states, exhibiting different geometries with unique properties, novel reactivity, and infinite applications. ${ }^{1}$ Schiff bases form an important class of organic compounds prepared by condensation of an aliphatic or aromatic primary amine with carbonyl compound. ${ }^{2}$ Schiff bases are the most favored ligands that can stabilize metal ions in different oxidation states. ${ }^{3}$ The formation of stable complexes with metal ions is due to nitrogen lone pair of electrons of azomethine $(-\mathrm{N}=\mathrm{CH})$ bonding in their structure. Imine complexes have a diversity of biological properties, including antitumor, antiviral, antifungal, antibacterial and so on activities. ${ }^{4}$ Non-steroidal anti-inflammatory drugs (NSAIDs) are used for treating different types of arthritis. The pharmacological activity of NSAIDs is related to the suppression of the enzyme prostaglandin endoperoxidase, commonly known as cyclo-oxygenase (COX). It was discovered that COX exists in two isoforms, COX-1 and COX-2, which are regulated and are expressed differently. Since long-term usage of NSAIDs causes gastrointestinal problems, it has become important to synthesis novel drugs with lesser side effects. ${ }^{5-10}$ Literature survey reveals that Schiff base metal complexes had shown promising anti-inflammatory activities. ${ }^{11,12}$ Therefore, the current study was aimed at preparing, spectrally analyzing, and biologically evaluating a Schiff base ligand and its metal complexes. 
RASĀYAN J. Chem.

Vol. 14 | No. 4 |2246-2254| October- December | 2021

\section{EXPERIMENTAL}

\section{Material and Methods}

All the chemicals and solvents used were of Sigma Aldrich (Analytical grade). The drug, diclofenac was purchased from Drugs India Mahaveeray, Hyderabad, India and was used without any further purification. The ethanol was distilled and then used as a solvent for synthesis. Melting points determined are uncorrected and TLC (Thin layer chromatography) was used to test the compound for the completion of the reaction. Elemental analysis was carried out using an elemental analyzer instrument. The molar conductance of the synthesized complexes in $1 \times 10^{-3} \mathrm{~mol} \mathrm{dm}^{3}$ DMF solution was measured using ELICO digital conductivity meter of CM-180 model. The infrared spectra of the ligand and complexes were recorded in FTIR Shimadzu spectrometer in the range $4000-400 \mathrm{~cm}^{-1}$ by $\mathrm{KBr}$ pellets method. The electronic spectra were recorded by using 20 spectronic instruments. The ${ }^{1} \mathrm{H}$ NMR spectrum was obtained from IISC, Bangalore, India. Mass spectrum of the Schiff base ligand was recorded on Micromass UK PLATFORM II LC-MS Spectrometer.

\section{General Procedure}

The conversion of (2-(2-(phenylamino)phenyl)acetyl)sodium (Diclofenac sodium) to 2-(2(phenylamino)phenyl)acetic acid (Diclofenac acid) was done by taking approximately $250 \mathrm{~mL}$ of distilled water in a beaker and by heating it. To the hot water, $30 \mathrm{~g}$ of sodium diclofenac was added pinch by pinch until it was completely dissolved. This solution was kept in ice-cold water for some time and then $6 \mathrm{~N}$ $\mathrm{HCl}(250 \mathrm{~mL})$ was added with constant stirring, the precipitate was obtained. The precipitate thus obtained from the above process was diclofenac acid. The precipitate was recrystallized in ethanol.

The compound 4-amino-5-(2-(phenylamino)benzyl)-1,2,4-triazolidine-3-thione was synthesized as follows: Firstly, the compound 1,3-diaminothiourea (thiocarbohydrazide) was prepared by referring to the reported literatures ${ }^{13,14}$ and then the compound 4-amino-5-(2-(phenylamino)benzyl)-1,2,4-triazolidine-3thione was synthesized by the fusion of thiocarbohydrazide and diclofenac acid in 1:1 molar ratio at $180{ }^{\circ} \mathrm{C}$ for about 3 hours. The fused mass formed was triturated with hot water. The precipitate obtained was filtered, washed with sodium bicarbonate solution, dried and finally recrystallized using ethanol. ${ }^{15}$

The compound 2-(((3-mercapto-5-(-2-(phenylamino)benzyl)-1,2,4-triazolidin-4-yl)imino)methyl)phenol (Schiff base ligand) was synthesized by mixing an equimolar ratio of 4-amino-5-(2(phenylamino)benzyl)-1,2,4-triazolidine-3-thione and salicylaldehyde. This solution was refluxed for about 5 hours. The yellow-colored precipitate formed was the Schiff base ligand. It was filtered, washed several times with water, dried and recrystallized in ethanol.

The synthesis of metal complexes was carried out by concentrating an ethanolic solution of the respective metal salts $\mathrm{Cu}(\mathrm{II}), \mathrm{Co}(\mathrm{II}), \mathrm{Ni}(\mathrm{II})$, and $\mathrm{Zn}(\mathrm{II})$ with an ethanolic solution of Schiff base ligand in 1:2 (metal: ligand) molar ratio and the solution was heated under reflux for about 3 hours. The colored precipitates obtained were filtered, washed several times with water and dried.

\section{RESULTS AND DISCUSSION}

The synthesized Schiff base ligand and its metal complexes were found to be intensely colored, stable at room temperature, soluble in solvents like DMF and DMSO. The elemental analysis data represented in Table-1 shows that they are in good agreement with those calculated for the suggested molecular formulae revealing that the complexes have 1:2 metal-ligand stoichiometry ratio. ${ }^{16,17}$ The molar conductance values for the complexes were found to be very low and so they are considered as nonelectrolytes.

Table-1: Elemental Analytical Data of Schiff Base Ligand and its Metal Complexes.

\begin{tabular}{c|c|c|c|c|c}
\hline \multirow{2}{*}{ Ligand/Complexes } & Physical & \multicolumn{4}{|c}{ Elemental Analysis (Observed, Calculated) \% } \\
\cline { 3 - 6 } & Color & $\mathrm{C}$ & $\mathrm{H}$ & $\mathrm{N}$ & Metal \\
\hline $\mathrm{C}_{22} \mathrm{H}_{23} \mathrm{~N}_{5} \mathrm{OS}$ & Yellow & $65.20(65.16)$ & $5.60(5.72)$ & $17.25(17.27)$ & ----------- \\
\hline $\mathrm{C}_{44} \mathrm{H}_{42} \mathrm{CuN}_{10} \mathrm{O}_{2} \mathrm{~S}_{2}$ & Brown & $60.75(60.71)$ & $4.80(4.86)$ & $16.20(16.09)$ & $7.75(7.30)$ \\
\hline $\mathrm{C}_{44} \mathrm{H}_{42} \mathrm{CoN}_{10} \mathrm{O}_{2} \mathrm{~S}_{2}$ & Red & $61.11(61.03)$ & $4.04(4.08)$ & $16.51(16.18)$ & $6.86(6.81)$ \\
\hline $\mathrm{C}_{44} \mathrm{H}_{42} \mathrm{NiN}_{10} \mathrm{O}_{2} \mathrm{~S}_{2}$ & Yellow & $61.09(61.05)$ & $4.72(4.89)$ & $16.60(16.18)$ & $6.60(6.78)$ \\
\hline $\mathrm{C}_{44} \mathrm{H}_{42} \mathrm{ZnN}_{10} \mathrm{O}_{2} \mathrm{~S}_{2}$ & Cream & $60.72(60.58)$ & $4.22(4.85)$ & $16.55(16.06)$ & $7.77(7.49)$ \\
\hline
\end{tabular}


RASĀYAN J. Chem.

Vol. 14 | No. 4 |2246-2254| October- December | 2021

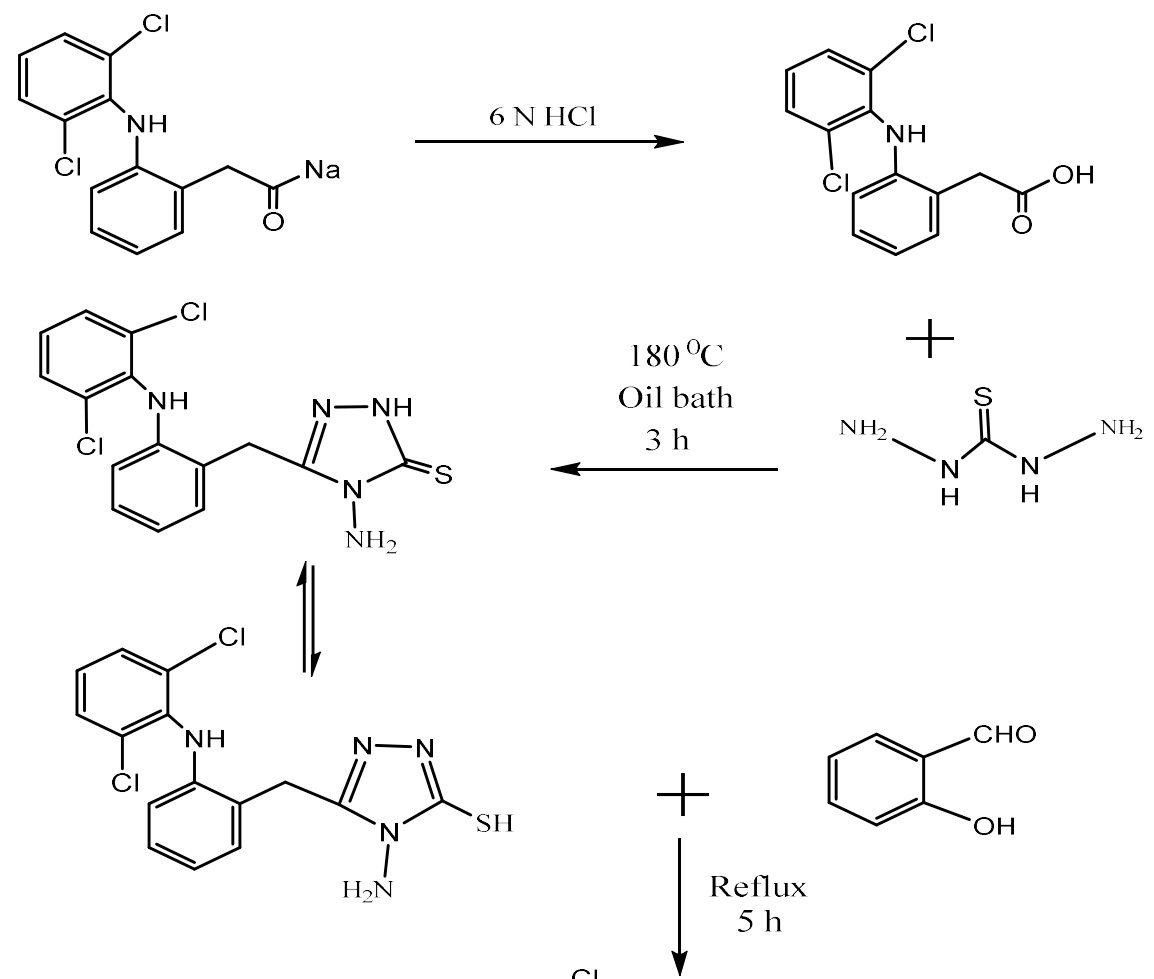<smiles>Oc1ccccc1C=Nn1c(S)nnc1Cc1ccccc1Nc1c(Cl)cccc1Cl</smiles>

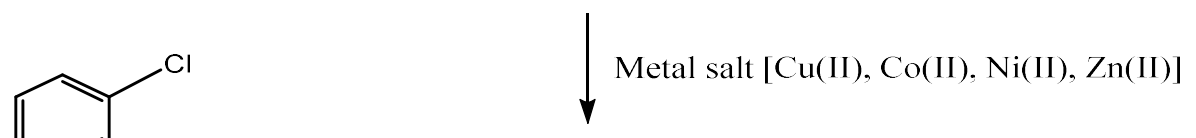

\section{Infrared Spectra}

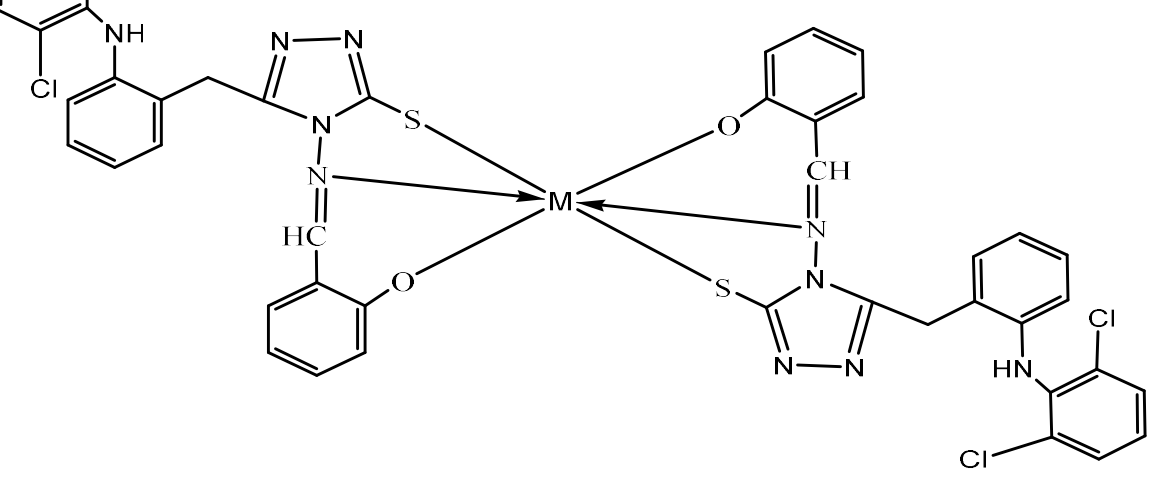

$\mathrm{M}=\mathrm{Cu}(\mathrm{II}), \mathrm{Co}(\mathrm{II}), \mathrm{Ni}(\mathrm{II}), \mathrm{Zn}(\mathrm{II})$

Scheme-1

The comparative study of the Infrared (IR) spectra of the Schiff base ligand and its metal complexes gives valuable information regarding the nature of functional groups coordinated to the metal atom. ${ }^{18}$ The selected IR Spectral data is represented in Table-2. The IR spectra of complexes indicate that Schiff base 
RASĀYAN J. Chem.

Vol. 14 | No. 4 |2246-2254| October- December | 2021

ligand coordinates with metals via - SH group of triazole, azomethine nitrogen group and phenolic $-\mathrm{OH}$ group. The Schiff base ligand shows a peak at $1640 \mathrm{~cm}^{-1}$ which can be assigned to $\mathrm{C}=\mathrm{N}$ (azomethine) group. The same peak in all the metal complexes has been shifted towards the lower wavenumber by 20$30 \mathrm{~cm}^{-1}$. This indicates that complexation has taken place through azomethine group. The peak at 3272 $\mathrm{cm}^{-1}$ has appeared in the Schiff base ligand and is due to the phenolic -OH group. This peak is absent in all the metal complexes which indicate the involvement of the phenolic group in complex formation. Further the -SH group in Schiff base ligand has been assigned at $2926 \mathrm{~cm}^{-1}$. This peak doesn't appear in all the metal complexes indicating that complexation also occurred from - $\mathrm{SH}$ group. Moreover, the new peaks in the range of 764-743, 671-641, and $476-436 \mathrm{~cm}^{-1}$ in all the metal complexes are due to M-O, MS and M-N bonding, respectively. ${ }^{19-22}$

Table-2: Selected Infrared Data of the Schiff Base Ligand and its Metal Complexes

\begin{tabular}{c|c|c|c|c|c|c}
\hline \multirow{2}{*}{ Compounds } & \multicolumn{5}{|c|}{ Wavenumber(cm-1) } & \\
\cline { 2 - 7 } & $v(\mathrm{O}-\mathrm{H})$ & $v(\mathrm{~S}-\mathrm{H})$ & $v(\mathrm{C}=\mathrm{N})$ & $v(\mathrm{M}-\mathrm{O})$ & $v(\mathrm{M}-\mathrm{N})$ & $v(\mathrm{M}-\mathrm{S})$ \\
\hline Schiff base ligand & 3272 & 2926 & 1640 & - & - & - \\
\hline Copper complex & - & - & 1617 & 743 & 671 & 476 \\
\hline Cobalt complex & - & - & 1621 & 755 & 641 & 436 \\
\hline Nickel complex & - & - & 1596 & 764 & 645 & 448 \\
\hline Zinc complex & - & - & 1617 & 743 & 671 & 476 \\
\hline
\end{tabular}

\section{Electronic Spectra and Magnetic Susceptibility}

The electronic spectra of complexes provide valuable information regarding the stereochemistry of metal ions in complexes. ${ }^{23}$ The electronic spectra of all the compounds were obtained in DMSO solution and the results are tabulated in Table-3. The electronic spectrum of Schiff base ligand shows two bands at 298 and $371 \mathrm{~nm}$ which can be attributed due to $\pi \rightarrow \pi^{*}, \quad n \rightarrow \pi^{*}$, intraligand charge transfer transitions of benzene and non-bonding electrons present on the nitrogen atom of azomethine group. The $\mathrm{Cu}$ (II) is a $\mathrm{d}^{9}$ ion and provides a good example for the John-Teller effect. The electronic spectrum of Cu (II) complex shows absorption bands at 343 and $670 \mathrm{~nm}$ due to ${ }^{2} \mathrm{~B}_{1 \mathrm{~g}} \rightarrow{ }^{2} \mathrm{E}_{\mathrm{g}},{ }^{2} \mathrm{~B}_{1 \mathrm{~g}} \rightarrow \rightarrow^{2} \mathrm{~A}_{1 \mathrm{~g}}$ transitions. The magnetic moment value for $\mathrm{Cu}$ (II) complex is $1.82 \mathrm{BM}$. These studies indicate that $\mathrm{Cu}$ (II) complex possesses octahedral geometry. The magnetic moment of Co (II) at room temperature shows a value of $4.75 \mathrm{BM}$ and exhibits three bands at 332, 642, and $681 \mathrm{~nm}$ due to ${ }^{3} \mathrm{~T}_{2 \mathrm{~g}}(\mathrm{~F}) \rightarrow{ }^{3} \mathrm{~T}_{1 \mathrm{~g}}(\mathrm{P}), \quad{ }^{4} \mathrm{~T}_{1 \mathrm{~g}}(\mathrm{~F}) \rightarrow{ }^{4} \mathrm{~T}_{2 \mathrm{~g}}(\mathrm{~F})$, ${ }^{4} \mathrm{~T}_{1 \mathrm{~g}}(\mathrm{~F}) \rightarrow{ }^{4} \mathrm{~T}_{2 \mathrm{~g}}(\mathrm{~F})$ transitions. This can be explained based on octahedral symmetry which involves a high degree of orbital contribution. The Ni (II) complex exhibits bands at 250, 303, 636 and $684 \mathrm{~nm}$ which may be due to $\pi \rightarrow \pi^{*},{ }^{3} \mathrm{~T}_{2 \mathrm{~g}}(\mathrm{~F}) \rightarrow{ }^{3} \mathrm{~T}_{1 \mathrm{~g}}(\mathrm{P}),{ }^{3} \mathrm{~T}_{2 \mathrm{~g}}(\mathrm{~F}) \rightarrow{ }^{3} \mathrm{~T}_{1 \mathrm{~g}}(\mathrm{~F}),{ }^{3} \mathrm{~T}_{2 \mathrm{~g}}(\mathrm{~F}) \rightarrow{ }^{3} \mathrm{~T}_{1 \mathrm{~g}}(\mathrm{~F})$ transitions. Ni (II) complex shows a magnetic moment value at $3.16 \mathrm{BM}$ depending upon the magnitude of orbital contribution. These observations suggest that $\mathrm{Ni}$ (II) possess an octahedral configuration in the complexes. $\mathrm{Zn}$ (II) is diamagnetic with $\mathrm{d}^{10}$ configuration and therefore it does not show any $\mathrm{d}-\mathrm{d}$ transitions. ${ }^{24-26}$

\section{${ }^{1}$ H NMR Spectra}

The ${ }^{1} \mathrm{H}$ NMR spectrum of the drug diclofenac and Schiff base ligand were recorded in DMSO solvent and are represented in Fig.-1 and 2. ${ }^{27}$ When compared the spectrum of diclofenac drug to that of Schiff base ligand, the following changes have been noted. In the spectrum of the drug, the peak at $\delta 3.697 \mathrm{ppm}$ is due to the presence of $-\mathrm{CH}$ protons whereas the same peak appears at $\delta 4.115 \mathrm{ppm}$ in the spectrum of ligand. The appearance of multiplets in the region $\delta 6.275-7.532 \mathrm{ppm}$ in drug spectrum can be assigned to the aromatic protons, these peaks in the Schiff base ligand spectrum appear between $\delta 6.234-7.76 \mathrm{ppm}$. A signal at $\delta 7.972 \mathrm{ppm}$ can be seen in the ligand spectrum and this can be mainly assigned because of azomethine group $(\mathrm{HC}=\mathrm{N})$ group of Schiff base ligand whereas there is no such peak in the drug spectrum. The -NH proton peak in the drug spectrum appears at $\delta 12.673 \mathrm{ppm}$ and in the ligand spectrum, 
RASĀYAN J. Chem.

Vol. 14 | No. 4 |2246-2254| October- December | 2021

it has appeared at $\delta 10.594 \mathrm{ppm}$. Further, in the ligand spectrum, a singlet peak at $\delta 10.684 \mathrm{ppm}$ can be seen and this can be assigned due to the $-\mathrm{OH}$ proton of salicylaldehyde and also a singlet at $\delta 13.592 \mathrm{ppm}$ mainly corresponded due to -SH proton of triazole ring. These peaks are absent in the drug spectrum. Therefore, these results confirmed the formation of Schiff base ligand. ${ }^{28-33}$

Table-3: Electronic Spectral Data of Schiff Base Ligand and its Metal Complexes

\begin{tabular}{c|c|c}
\hline Compounds & Absorption Bands (nm) & Assigned Transitions \\
\hline Schiff base ligand & 298,371 & $\pi \rightarrow \pi, \mathrm{n} \rightarrow \pi^{2}$ \\
\hline Copper complex & 343,670 & ${ }^{2} \mathrm{~B}_{1 \mathrm{~g}} \rightarrow \mathrm{E}_{\mathrm{g},}{ }^{2} \mathrm{~B}_{1 \mathrm{~g}} \rightarrow \mathrm{A}_{1 \mathrm{~g}}$ \\
\hline Cobalt complex & $332,642,681$ & ${ }^{3} \mathrm{~T}_{1 \mathrm{~g}}(\mathrm{~F}) \rightarrow{ }^{3} \mathrm{~T}_{1 \mathrm{~g}}(\mathrm{P}),{ }^{4} \mathrm{~T}_{1 \mathrm{~g}}(\mathrm{~F}) \rightarrow{ }^{4} \mathrm{~T}_{2 \mathrm{~g}}(\mathrm{~F})$, \\
& & ${ }^{4} \mathrm{~T}_{1 \mathrm{~g}}(\mathrm{~F}) \rightarrow{ }^{4} \mathrm{~T}_{2 \mathrm{~g}}(\mathrm{~F})$ \\
\hline Nickel complex & $250,303,636,684$ & $\pi \rightarrow \pi^{3},{ }^{3} \mathrm{~T}_{2 \mathrm{~g}}(\mathrm{~F}) \rightarrow{ }^{3} \mathrm{~T}_{1 \mathrm{~g}}(\mathrm{P})$, \\
\hline Zinc complex & & ${ }^{3} \mathrm{~T}_{2 \mathrm{~g}}(\mathrm{~F}) \rightarrow{ }^{3} \mathrm{~T}_{1 \mathrm{~g}}(\mathrm{~F}),{ }^{3} \mathrm{~T}_{2 \mathrm{~g}}(\mathrm{~F}) \rightarrow{ }^{3} \mathrm{~T}_{1 \mathrm{~g}}(\mathrm{~F})$ \\
\hline
\end{tabular}

D

Fig. $-1.1{ }^{1} \mathrm{H}$ NMR Spectrum of Diclofenac Drug

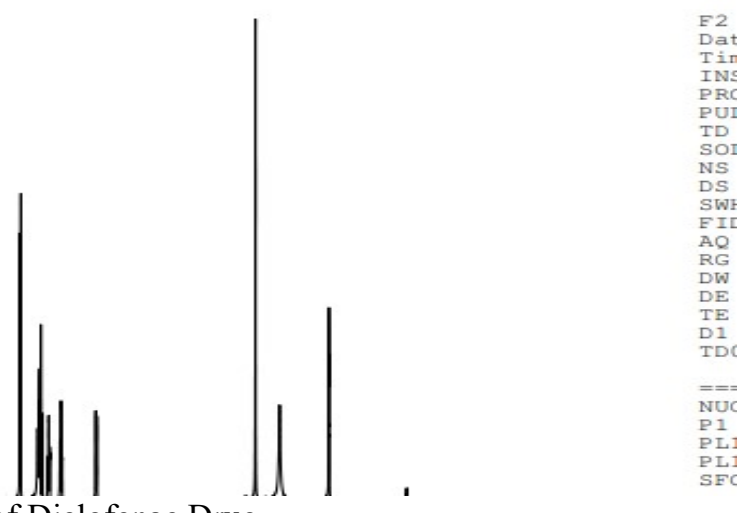

(a)

DSB

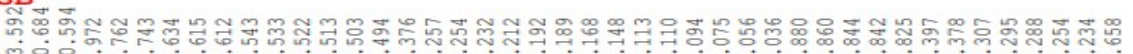

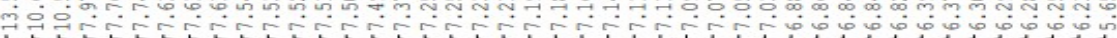

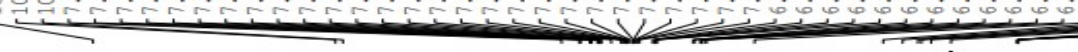

|

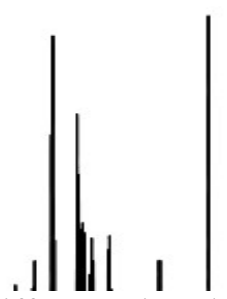

Fig.-2: ${ }^{1} \mathrm{H}$ NMR Spectrum of Schiff Base Ligand

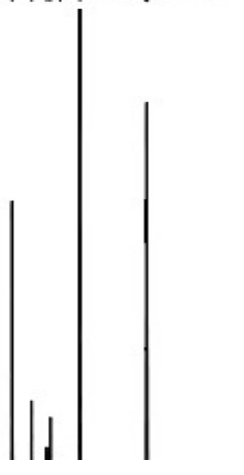


RASĀYAN J. Chem.

Vol. 14 | No. 4 |2246-2254| October- December | 2021

\section{Mass Spectrum}

In addition to the ${ }^{1} \mathrm{H}$ NMR Spectrum, the Schiff base ligand $\left(\mathrm{C}_{22} \mathrm{H}_{17} \mathrm{Cl}_{2} \mathrm{~N}_{5} \mathrm{OS}\right)$ has also been confirmed from its mass spectrum which is represented in Fig.-3. The mass spectrum of the Schiff base ligand showed a molecular ion peak at $\mathrm{m} / \mathrm{z} 469.88$ which coincides with the proposed molecular weight for the Schiff base ligand. (469.05). The various other peaks observed are due to fragmentations at different stages. $^{34,35}$
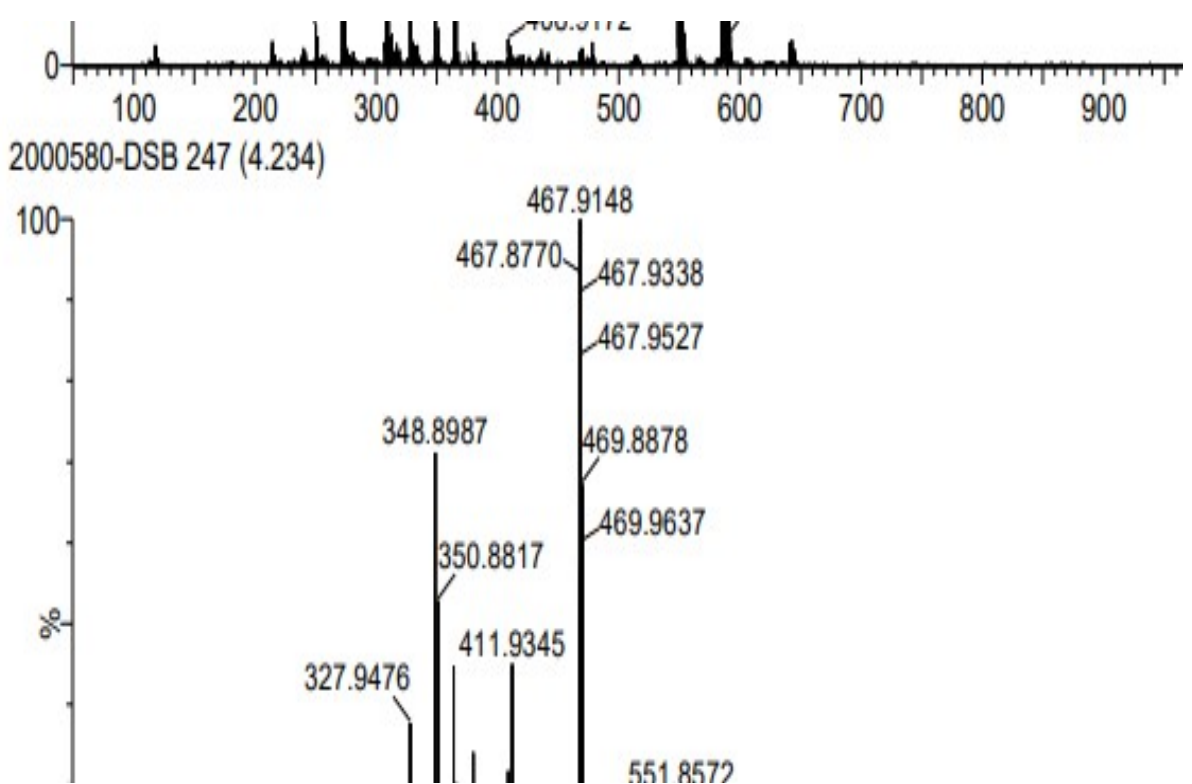

\section{Antimicrobial Analysis}

Fig.-3: Mass Spectrum of the Schiff Base Ligand.

The drug diclofenac, newly synthesized Schiff base ligand and its metal complexes were screened for antibacterial and antifungal activities. The compounds were dissolved in DMSO solvent. For antibacterial analysis, Gram +ve Staphylococcus aureus and Gram -ve Escherichia coli were used and for antifungal activity, Penicillium brocae and Aspergillus terreus fungal strains were chosen. Antibacterial activity was performed on nutrient agar medium, Czapek dox agar medium was used for antifungal activity. The zones of inhibition in mm have been recorded and the results are shown in Tables- 4 and $5 .^{36-43}$

Table-4: Antibacterial Activity of Drug, Ligand, and Metal Complexes

\begin{tabular}{c|c|c|c|c|c|c}
\hline \multirow{2}{*}{ Compounds } & \multicolumn{3}{|c}{ E.coli $(\mathrm{mm})$} & \multicolumn{3}{c}{ S. aureus $(\mathrm{mm})$} \\
\cline { 2 - 7 } & $20 \mu \mathrm{g} / \mathrm{mL}$ & $50 \mu \mathrm{g} / \mathrm{mL}$ & $100 \mu \mathrm{g} / \mathrm{mL}$ & $20 \mu \mathrm{g} / \mathrm{mL}$ & $50 \mu \mathrm{g} / \mathrm{mL}$ & $100 \mu \mathrm{g} / \mathrm{mL}$ \\
\hline Diclofenac & 2 & 0 & 0 & 0 & 0 & 0 \\
\hline Schiff base Ligand & 0 & 0 & 0 & 5 & 0 & 0 \\
\hline Cu complex & 2 & 0 & 0 & 0 & 0 & 0 \\
\hline Co complex & 0 & 0 & 0 & 0 & 0 & 0 \\
\hline Ciprofloxacin (standard) & 25 & 32 & 36 & 28 & 36 & 48 \\
\hline
\end{tabular}

Table-5: Antifungal Activity of the Drug, Ligand and Metal Complexes

\begin{tabular}{c|c|c|c|c|c|c}
\hline \multirow{2}{*}{ Compounds } & \multicolumn{3}{|c|}{ P. brocae $(\mathrm{mm})$} & \multicolumn{3}{c}{ A. terreus $(\mathrm{mm})$} \\
\cline { 2 - 7 } & $20 \mu \mathrm{g} / \mathrm{mL}$ & $50 \mu \mathrm{g} / \mathrm{mL}$ & $100 \mu \mathrm{g} / \mathrm{mL}$ & $20 \mu \mathrm{g} / \mathrm{mL}$ & $50 \mu \mathrm{g} / \mathrm{mL}$ & $100 \mu \mathrm{g} / \mathrm{mL}$ \\
\hline Diclofenac & 3 & 0 & 0 & 0 & 0 & 0 \\
\hline Schiff base Ligand & 2 & 0 & 0 & 5 & 0 & 0 \\
\hline Cu complex & 1 & 0 & 0 & 0 & 0 & 0 \\
\hline Zn complex & 2 & 0 & 0 & 0 & 0 & 0 \\
\hline Ciprofloxacin (standard) & 20 & 31 & 38 & 30 & 33 & 38 \\
\hline
\end{tabular}

\section{Anti-inflammatory Activity}

The transcription factor nuclear kappa $\mathrm{B}(\mathrm{NF}-\mathrm{\kappa} \mathrm{B})$ plays a major role in innate immunity and inflammatory responses and it is considered the major link between inflammation and tumorigenesis. In 
RASĀYAN J. Chem.

Vol. 14 | No. 4 |2246-2254| October- December | 2021

this study, Test Compounds namely D3 (Diclofenac drug), DCU-1 (Cu complex), DSB-2 (Schiff base ligand) and DZN-1 (Zn complex) were used to evaluate the Pro inflammatory marker (PE conjugated Mouse anti-NF-kB p65 antibody) expression Study on the LPS stimulated cell line namely, Raw 264.7. The test compounds, D3, DCU1, DSB2 and DZN1 with the nontoxic concentration viz., $25 \mathrm{ug} / \mathrm{mL}$ showed 23.21, 34.29, 22.45, and 33.74 in terms of mean fluorescence intensity of NF-kB expression respectively, after the pre-stimulation of Raw 264.7 cell line with Lipopolysachride $(2 \mathrm{ug} / \mathrm{mL})$. The LPS alone showed 109.72 mean fluorescence intensity of NF-kB compared to the cell control without LPS treatment showing 10.61 mean fluorescence intensity of NF-kB expression respectively. ${ }^{44-49}$ Figure-4 represents mean fluorescence intensity values of NF-kB against the Untreated, LPS alone and drug with a combination of LPS stimulated Raw 264.7 cells.

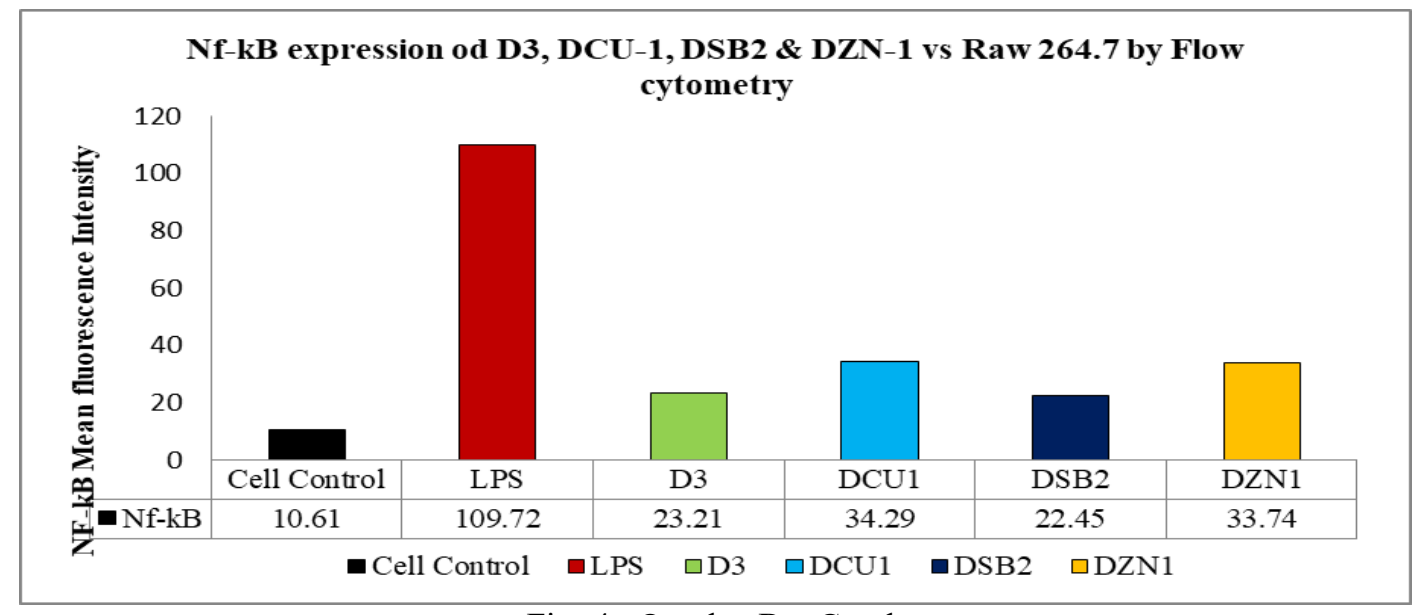

Fig.-4: Overlay Bar Graph

\section{CONCLUSION}

The study of analytical and spectral data suggested that the metal complexes exhibit octahedral geometry with 1:2 metal to ligand ratio. The antimicrobial analysis shows that the ligand and metal complexes show better activities than the original drug, diclofenac and this can be explained based on the overtone concept and Tweedy chelation theory. The anti-inflammatory observations suggest that the metal complexes possess satisfactory anti-inflammatory potential properties in the Raw 264.7 cell line by suppressing the expression of pro-inflammatory cytokine (NF-kB) compared to the LPS treated Raw 264.7 cells expression.

\section{ACKNOWLEDGEMENT}

The author K.G. Shilpa thanks VSK University, Ballari, Karnataka, India for providing fellowship under $\mathrm{SC} / \mathrm{ST}$ scheme.

\section{REFERENCES}

1. Jai Devi, Manju Yadav, Anil Kumar, Ashwani Kumar, Chemical Papers, 72, 2479(2018), https://doi.org/10.1007/s11696-018-0480-0

2. Sheida Esmaielzadeh and Elham Zarenezhad, Acta Chimica. Slovenica, 65, 416(2008), https://doi.org/10.17344/acsi.2018.4159

3. Ranjan K. Mohapatra, Pradeep K. Das, Manoj K. Pradhan, Abdussalam A. Maihub and Marei M. EIajaily, Journal of the Iranian Chemical Society, 15, 2193(2008), https://doi.org/10.1007/s13738018-1411-2

4. A.Z. El-Sonbati, W.H. Mahmoud, Gehad G. Mohamed, M.A. Diab, Sh.M. Morgan, S.Y. Abbas, Applied Organometallic Chemistry, 33(9), 1(2019), https://doi.org/10.1002/aoc.5048

5. Kavita Rana, Annamalai Pandurangan, Namrata Singh, Amit Kumar Tiwari, International Journal of Current Pharmaceutical Research, 4(2), 5(2012)

6. Tong J Gan, Current Medical Research and Opinion, 26(7), 1715(2010), https://doi.org/10.1185/03007995.2010.486301

7. Dimitra Kovala-Demertzi, Journal of Inorganic Biochemistry, 79, 153(2000) 
RASĀYAN J. Chem.

Vol. 14 | No. 4 |2246-2254| October- December | 2021

8. G.Y. Aguilar-Lira, G.A. Álvarez-Romero, A. Zamora-Suárez , M. Palomar-Pardavé, A. RojasHernández, J.A. Rodríguez-Ávila , M.E. Páez-Hernández, Journal of Electroanalytical Chemistry, 794, 182(2017), https://doi.org/10.1016/j.jelechem.2017.03.050

9. Ademar Wong, Luiz D. Marestoni and Maria D. P. T. Sotomayor, Journal of Brazalian Chemical Society, 25(7), 1283(2014).

10. Lili Wei \& Joanna Borowiec \& Lihua Zhu \& Jingdong Zhang, Jounal of Solid State Electrochemistry, 16, 3817(2012), https://doi.org/10.1007/s10008-012-1815-3

11. Anu Kajal, Suman Bala, Sunil Kamboj, Neha Sharma, and Vipin Saini, Journal of Catalysts, 2003, 1(2003), https://doi.org/10.1155/2013/893512

12. Kumar Abhishek, Fernandes Jennifer, Kumar Pankaj, International Journal of Drug Development and Research, 6(2), 165(2014)

13. Vaibhav Sharma, Dinesh Kumar Mehta, Rina Das, Preet Kawal Kaur, International Journal of $\begin{array}{llll}\text { Pharmacy and } & \text { Pharmaceutical }\end{array}$ https://doi.org/10.22159/ijpps.2016.v8i9.11269

14. Avinash Nalawade, RekhaNalawade, Balaji Londhe, International Journal of ChemTech Research, 10(6), 553(2017)

15. Parminder Kaur, Rajwant Kaur, Manish Goswami, International Research Journal of Pharmacy, 9 (7), 1(2018), https://doi.org/10.7897/2230-8407.097121

16. V.B. Badwalk, R.D. Deshmukh and A.S. Aswar, Journal of Coordination Chemistry, 62(12), 2037(2009), https://doi.org/10.1080/00958970902741244

17. Amina Mumtaz, and Tariq Mahmud, Pakistan Journal of Pharmaceutical Sciences, 32(3), 963(2019)

18. M. J. Jisha, C. Isac Sobana Raj, Asian Journal of Research in Chemistry, 10(6), 765(2017), https://doi.org/10.5958/0974-4150.2017.00129.8

19. Suman Malik, Suparna Ghosh, Bharti Jain, Archana Singh, and Mamta Bhattacharya, International Journal of Inorganic Chemistry, 2013,1(2013), https://doi.org/10.1155/2013/549805

20. Zahra Shokohi-pour, Hossein Chiniforoshan, Amir Abbas Momtazi-borojeni , Behrouz Notash, Journal of Photochemistry and Photobiology B: Biology, 162, 34(2016), https://doi.org/10.1016/j.jphotobiol.2016.06.022

21. Emad Yousif, Ahmed Majeed, Khulood Al-Sammarrae, Nadia Salih, Jumat Salimon, Bashar Abdullah, Arabian Journal of Chemistry, 10, S1639(2017), https://doi.org/10.1016/j.arabjc.2013.06.006

22. Mehmet Tumer, Eyup Akgun, Sev-il Torog, Ahmet Kayraldiz and Laledonbak, Journal of Coordination Chemistry, 61(18), 2935(2008), https://doi.org/10.1080/00958970801989902

23. Ahmad S. Abu-Khadra, Ahmed S. Afify, Amr Mohamed, Rabie S. Farag and Hassan Y. AboulEnein, The Open Bioactive Compounds Journal, 6, 1(2018), https://doi.org/10.2174/1874847301806010001

24. Methaq Saeed Mohamad, Acta Chimica and Pharmaceutica Indica, 3(2), 140(2013)

25. Basim Hatim Al-Zaidi, Mohammed Mujbel Hasson, Ahmad Hussein Ismail, Journal of Applied Pharmaceutical Science, 9(04), 45(2019), https://doi.org/10.7324/JAPS.2019.90406

26. Rawand Alsabra, Lena Radwan, Chemistry and Materials Reasearch, 8(7), 76(2016)

27. K. T. Bharati, D. B. Gujarathi, P. T. Tryambake, G J. Hase, R. K. Gaikwad and Khatal, Der Chemica Sinica, 8(2), 223(2017).

28. Kavitha Andiappan, Anandhavelu Sanmugam, Easwaramoorthy Deivanayagam, K. Karuppasamy, Hyun-Seok Kim \& Dhanasekaran Vikraman, Scientific Reports, 8, 1(2018), https://doi.org/10.1038/s41598-018-21366-1

29. T. Topala, E. Karapınara, E. Journal of the Turkish Chemical Society, 5(2), 785(2018), http://dx.doi.org/10.18596/jotcsa.324878

30. Chandra Mohan, Vinod Kumar, Sarla Kumari, International Research Journal of Pharmacy, 9 (7), 153(2018), https://doi.org/10.7897/2230-8407.097141

31. Prateek Tyagi, Monika Tyagi, Swati Agrawal, Sulekh Chandra, Himanshu Ojha, Mallika Patha, Spectrochim Acta, 30461(9), 1386(2016). 
RASĀYAN J. Chem.

Vol. 14 | No. 4 |2246-2254| October- December | 2021

32. Sajjad H. Sumrra \& Zahid H. Chohan, Journal of Enzyme Inhibition and Medicinal Chemistry, 28(6), 1291(2013), https://doi.org/10.3109/14756366.2012.735666

33. Kiran Singh, Yogender Kumar, Parvesh Puri and Gulab Singh, Bioinorganic Chemistry and Applications, 2012, 1(2012), https://doi.org/10.1155/2012/729708

34. Gehad Geindy Mohamed, Mohamed Mohamed Omar, Ahmed Mohamed Hindy, Turkish Journal of Chemistry, 30, 361(2006)

35. Ovas Ahmad Dar, Shabir Ahmad Lone, Manzoor Ahmad Malik, Faisal Mohammed Aqlan, Mohmmad Younus Wani, Athar Adil Hashmi, Aijaz Ahmad, Heliyon, 5(7), e02055(2019), https://doi.org/10.1016/j.heliyon.2019.e02055

36. Emad Yousif, Ahmed Majeed, Khulood Al-Sammarrae, Nadia Salih, Jumat Salimon, Bashar Abdullah, Arabian Journal of Chemistry, 10(2), S1639(2017), https://doi.org/10.1016/j.arabjc.2013.06.006

37. S.Arulmurugan, Helen P. Kavitha and B.R. Venkatraman, Rasayan Journal of Chemistry, 3(3), 385(2010).

38. Suzan A. Matar, Wamidh H. Talib, Mohammad S. Mustafa, Mohammad S. Mubarak, Murad A. Al Damen, Arabian Journal of Chemistry, 8(6), 850(2015), https://doi.org/10.1016/j.arabjc.2012.12.039

39. Anaja Omanakuttan, G. Priyanka, R. Divya Mohan, Material Science and Engineering, 561, 1(2019), https://doi.org/10.1088/1757-899X/561/1/012050

40. Bhushan Nazirkar, Mustapha Mandewale and Ramesh Yamgar, Journal of Taibah University for Science, 13(1), 440(2019), https://doi.org/10.1080/16583655.2019.1592316

41. F. K. Ommenya, E. A. Nyawade, D. M. Andala, and J. Kinyua, Hindawi Journal of Chemistry, 2020, 1(2020), https://doi.org/10.1155/2020/1745236

42. G.R. Pandhare, V.M. Shindea, Y.H. Deshpandeb, Rasayan Journal of Chemistry, 2, 337(2008).

43. Prashant Singh and Rajesh K.S. Dhakarey, Rasayan Journal of Chemistry, 2(4), 869(2009).

44. Natoli G, Saccani S, Bosisio D, Marazzi I, Nature Immunology, 6(5), 439(2005), https://doi.org/10.1038/ni1196

45. Siebenlist U, Brown K, Claudio E, Nature Reviews Immunology, 5, 435(2005), https://doi.org/10.1038/nri1629

46. Viatour P, Merville M-P, Bours V, Chariot A, Trends in Biochemical Sciences, 30(1), 43(2005), https://doi.org/10.1016/j.tibs.2004.11.009

47. M. Karin, Nature, 441(7092), 431(2006), https://doi.org/10.1038/nature04870

48. R. Al-Halabi, M. Bou Chedid, R. Abou Merhi et al, Cancer Biology and Therapy, 12(1), 59(2011), https://doi.org/10.4161/cbt.12.1.15715

49. C. Gupta, C. Sundaram, S. Reuter, and B. B. Aggarwal, Biochima et Biophysica Acta, 1799 (12), 775(2010), https://doi.org/10.1016/j.bbagrm.2010.05.004

[RJC-6507/2021] 